\title{
СЛОВНИКИ ОНОМАСТИЧНИХ ТЕРМІНІВ У РОСІЙСЬКОМУ Й УКРАЇНСЬКОМУ МОВОЗНАВСТВІ: КОМПОЗИЦІЯ, СКЛАД, СПОСОБИ ІНТЕРПРЕТАЦЇ̈ ТА ПРОБЛЕМА ДЕФІНІЮВАННЯ
}

Стаття присвячена аналізу термінологічних ономастичних словників XX-XXI століть, укладених російськими й украйнськими вченими. Увагу приділено вивченню композиціі, принципів $і$ способів інтерпретації ономастичних термінів, а також проблемі їх дебініювання. Розглянуто специфіку міжмовних паралелей $і$ труднощі, що виникають у процесі інтерпретації нових ономастичних термінів. Дослідження доводить необхідність укладання сучасних двомовних $і$ багатомовних словників ономастичних термінів y зв'язку зі зростанням значення ономастики у світовій лінгвістиці, збільшенням їх кількості та відповідними змінами в їхній системі.

Ключові слова: ономастична термінологія, ономастичні словники, украйнська ономастика, російська ономастика, міжмовні паралелі.

Yanchura D. The Dictionaries of Homonymic Terms in Russian and Ukrainian Linguistics: Composition, Structure, Ways of Interpretation and the Issue of Definition. The article draws on the analysis of the range and structure of modern onomastic dictionaries of homonymic terminology in Russian and Ukrainian linguistics. The ways of interpreting certain concepts and determining terminological differences that occur in Ukrainian and Russian linguistics are discussed. The nature of the study that was conducted is descriptive and interpretative. The topicality of the present research lies in the fact that none of the modern research areas can develop without a standardised terminological system that ought to be characterised by international features, but at the same time by the preservation of national peculiarities.

Modern Russian and Ukrainian linguistics can boast about two monolingual specialised dictionaries dedicated to onomastic terminology: «The dictionary of Russian onomastic terminology» by N. Podolska, and "The dictionary of Ukrainian onomastic terminology", compiled by D. Buchko and N. Tkachova. The fact testifies to the small number of onomastic terminological dictionaries. The Russian dictionary compiled by N. Podolska can be regarded as somewhat outdated, considering the year of publication (1978) and a remarkable development of onomastics after it came out. Moreover, the dictionary contains a relatively small number of terms (700 entries). The Ukrainian dictionary is more up to date (issued in 2012) and contains more entries (2000 terms), but it would benefit from demonstrating the systemic character of onomastic terminology. It would be also worth highlighting the variety of use 
of onomastic terms, as onomastic terminology, Russian and Ukrainian in particular, is nowadays "fighting" with the issues of synonymy and pseudo-homonymy.

The findings of the study serve as evidence for the need to compile bilingual and multilingual dictionaries of onomastic terms. In the era of globalisation, it would also be useful to create the electronic edition of the multilingual dictionary of onomastic terminology similar to the ICOS system.

Keywords: onomastic terminology, onomastic dictionaries, Ukrainian onomastic, Russian onomastic, interlingual parallels.

\section{Вступ}

Проблема уніфікації термінології різних наукових галузей постійно перебуває в полі зору дослідників. На це, безумовно, впливають глобалізаційні процеси, що дають змогу вченим активно обмінюватися думками, популяризувати результати своїх досліджень (див. про це Космеда, 2019). До наук, що мають на сьогодні не зовсім упорядковану термінологічну систему, належить й ономастика.

Одним з головних аспектів XXI Міжнародної та Загальнопольської ономастичної конференції 2018 року була саме ономастична термінологія (Włoskowicz, 2018: 73). Наукова термінологія кожної мови, як підкреслював Василь Німчук, - явище національне за своїми витоками, але одночасно й інтернаціональне за сферою вживання (цит. за: Бучко, \& Ткачова, 2012: 5-6), тому створення інтернаціональної термінологічної системи з одночасним збереженням національних особливостей - актуальна проблема сучасної науки.

Мета цієї розвідки - проаналізувати обсяг і структуру російських та українських словників ономастичної термінології, виявити способи інтерпретації окремих понять та виокремити термінологічні відмінності, певні розбіжності.

Ономастика - це, як відомо, відносно молода наука, що досліджує сукупність власних назв як систему в різних аспектах; структуру онімів, їхнє функційне навантаження, принципи класифікації, типи тощо. У сучасному українському й російському мовознавстві простежуємо стрімкий розвиток цього розділу: протягом останніх років зростає кількість грунтовних наукових розвідок, що торкаються багатьох аспектів ономастики. Як зауважує український ономаст Дмитро Бучко, «якщо окрема наука динамічно розвивається, то і їі термінологія постійно збагачується, вдосконалюється - з'являються окремі нові терміни для позначення раніше невідомих понять, нововстановлених 
відношень, крім цього, існуючі раніше терміни нерідко вимагають певних уточнень» (Бучко, \& Ткачова, 2012: 6).

Польський дослідник Войсех Влоскович зауважує, що сьогодні неможливо стандартизувати ономастичну термінологію, спроба створення однакової й універсальної системи понять, вираженої оптимальною термінологічною системою в ономастиці $є$ неактуальною (Włoskowicz, 2018: 74). Зазначене було 6 спробою надання цій галузі схоластичного характеру, що не вписується в основне положення ономастики, а саме: ця наука ніколи не “говорить” “останнього слова" (Włoskowicz, 2018: 74).

Поява нових термінів у конкретній галузі науки чи культури «здійснюється поступово і $є$ своєрідним закріпленням результатів вивчення, пізнання окремих явищ і реалій об'єктивної дійсності, встановлення закономірностей розвитку чи змін цих явищ і ін.» (Бучко, \& Ткачова, 2012: 5). За відносно невеликий період розвитку ономастики простежуємо вихід у світ незначної кількості галузевих російських й українських словників, присвячених ономастичній термінології, хоч деякі ономастичні терміни з'являлися в неспеціальних лінгвістичних словниках (див. Загнітко, 2013; Ахманова, 1966).

\section{Методи дослідження}

Розвідка має оглядовий і дескриптивний характер з моделюванням проспекції. У дослідженні використано в основному описовий, інтерпретативний, порівняльно-зіставний методи, метод абстрагування, аналізу словникових дебінічій та ін., що спрямовані на вивчення сучасних словників ономастичних термінів, авторами яких $€$ російські й українські дослідники.

\section{Виклад основного матеріалу}

У 1963 році в Софії за рішенням V Міжнародного конгресу славістів було розпочато роботу над загальнослов'янським ономастичним термінологічним словником, запропонованим чеським ономастом Яном Свободою. Проєкт цього словника було видано в Празі. На його основі укладено словник слов'янської ономастичної термінології «Основная система и терминология славянской ономастики» (Скоп’ $€$, 1983). Його розробка почалася з виокремлення єдиної понятійної системи, що складається з універсальних понять, тобто незалежних від 
специфіки окремих мов. На жаль, цей словник на сьогодні вже дещо застарів, хоч і має відповідну цінність. Це словник-мінімум, оскільки містить лише 199 термінів. Як зауважує Ірина Казимирова, «у цій лексикографічній праці наведено основні ономастичні терміни та їхні відповідники 12-ма мовами (зокрема російською й українською Д. Я.) (...) із дефініціями. Словник поділено на дві частини: у першій подано терміни, які стосуються об’єктів і явищ позамовної дійсності (денотатів), позначених власними іменами; у другій подано терміни, які відбивають лінгвістичний аналіз власних імен, тобто належать до метамови ономастики» (Казимирова, 2013: 188). Згаданий словник і доповнення до нього стали основою подальших досліджень.

У контексті слов'янської ономастичної термінології згадаємо й про важливу для сучасної слов'янської ономастики засадничу статтю Михайла Торчинського й запропоновану ним концепцію словника української ономастичної термінології (див. Торчинський, 2008) та праці сучасного російського ономаста Василя Супруна, який актуалізував питання щодо потреби створення нового словника російських ономастичних термінів (див. Супрун, 2011), а також актуальну наукову розвідку Олександри Суперанської, у якій проаналізовано ввесь наявний на той час досвід ономастичних класифікацій, визначено засади класифікації власних назв на основі різноаспектних параметрів, описано групи й підгрупи розрядів онімів, однак на сьогодні вона також застаріла (див. Суперанская, 2009).

Важливим у світлі актуалізованої в цій науковій розвідці проблеми, безумовно, $\epsilon$ «Словарь русской ономастической терминологии» Наталії Подольської, виданий 1978 року й перевиданий через десять років. Цей словник уважають однією з найважливіших лексикографічних праць російської ономастичної термінології, однак на сьогодні він також потребує оновлення, оскільки не відображає останніх результатів досліджень у галузі ономастики. Словник Н. Подольської - це перший російський галузевий лінгвістичний одномовний тлумачний словник термінів, що нараховує близько 700 одиниць. На значущості цієї роботи наголошує М. Торчинський: «Класифікація пропріальної лексики, запропонована Н. В. Подольською у “Словнику російської ономастичної термінології” у вигляді шести схем, які грунтуються на різних підходах до традиції власних назв, звичайно, заслуговує на виняткову увагу; крім того, доповнення, наявні 
Янчура Д. Словники ономастичних термінів у російському й українському мовознавстві: композиція, склад...

у словникових статтях, дають змогу значно деталізувати ії і можуть бути основою для створення ономастичної термінології української мови» (Торчинський, 2008: 244).

Структура словника містить такі частини: «От автора» (с. 3-6), «Опыт отраслевого лингвистического словаря» (с. 7-16), «Как построен словарь» (с. 16-19), «Словарная статья» (с. 19-21), «Система отсылок» (с. 22), «Терминоэлементы греческого и латинского языков, регулярно входящие в специальные термины ономастики» (с. 23-24), «Словарные статьи» (с. 25-171), «Аббревиатуры терминов» (с. 172), «Библиография» (с. 173-180), «Указатели» (терминологический /c. 181-196/ и предметно-терминологический /с. 197-198/).

Частина «От автора» обумовлює значення термінології в ономастиці. Н. Подольська докладно описує витоки творення російської термінології загалом (передусім технічної, але й лінгвістичної), характеризує внесок різних дослідників у розробку ономастичної термінології та характеризує наявні на той час термінологічні словники й под. Зазначена вище авторка пропонує увазі читачів загальну інформацію про словник (кількість термінів, зауваження до їхнього тлумачення). У частині «Опыт отраслевого лингвистического словаря» дано характеристику ономастики як науки, передусім ономастичної термінології як складника лінгвістичної термінології загалом. Дослідниця зауважує, що «ономастика має свою особливу систему термінів, якими лінгвістика як така не користується, а якщо й користується, то запозичує їх в ономастики. Включаючи у свою структуру таку галузь, як ономастика, лінгвістика вже має всі підстави для створення галузевого термінологічного словника» (переклад автор. - Д. Я.) (Подольская, 1978: 7). У цьому самому підрозділі укладачка словника пропонує характеристику термінів, що ввійшли до термінологічного лексикону, характеризує принципи їх відбору, репрезентує авторську концепцію. Тут знаходимо загальну інформацію про (а) поняття термін, (б) способи творення термінів (зокрема термінів ономастики), (в) критерії оцінки структури та якості ономастичних термінів, (г) принципи їх побудови, а також (г) схеми, що ілюструють системність ономастичної термінології (субординацію, підпорядкованість). Н. Подольська наголошує, що терміни, які підлягають тлумаченню в ііі словнику, уживаються в роботах насамперед радянських ономастів (див. Подольская, 1978: 12). Зауважено, що до словника не включені 
терміни, репрезентовані в роботі Андрія Білецкого «Лексикология и теория языкознания (ономастика)» (див. Белецкий, 1972), що дослідниця пояснює так: «Ця термінологія настільки індивідуальна (...), що вона сама може репрезентувати предмет термінологічного словника. Включення термінології А. О. Білецького вимагало б незліченних застережень, відсилань і “перекладів” (переклад автор. - Д. Я.) (Подольская, 1978: 14). Н. Подольська звертає увагу й на специфіку розв’язання питання про статус терміна порівняно з нетерміном. Значну кількість близьких до термінів словосполучень, що вживаються в науковій ономастичній літературі, дослідниця систематизувала у вигляді додатка. Так само у вигляді додатка подано й терміни-композити, створені за конкретними моделями, зразки яких також проілюстровано. До словника ввійшли терміни-футуроніми, що ще на той час не вживали в науковій літературі, але їх появу можна було прогнозувати, напр., рос. анемоним - 'назва вітру або стихійного лиха', балероним - 'назва нагороди або відзнаки'. Сьогодні деякі термінифутуроніми вже встратили цей свій статус і перейшли до розряду загальновживаних, що активно функціюють у науковому мовленні. Частина «Как построен словарь» містить інформацію про основні принципи розміщення термінів у словнику. Терміни подані за алфавітно-гніздовим приципом. Перевага, зрозуміло, надається інтернаціоналізмам. Розділ «Словарная статья» містить чи не найважливішу інформацію. Словникова стаття в «Словаре...» складається з таких компонентів: 1. Вокабула. 2. Для термінів, що називають процеси, у квадратних дужках подано зразки вживання. 3. Варіанти основного терміна (менш активні, уживані, зокрема й застарілі, але зареєстровані в науковій літературі) подані безпосередньо після заголовного слова (або словосполучення) в круглих дужках. 4. Тлумачення, або визначення терміна, його дефініція. 5. Приклади до витлумаченого терміна (скорочено Пр.:). 6. Уживання терміна в словниках і в науковій літературі (скорочено Употр.:). 7. Походження терміна (скорочено Происх.:). 8. Примітки (скорочено Прим.:), де запропоновано додаткову інформацію, як-от: а) енциклопедична довідка; б) пояснення до структури ВН певної категорії; в) відсилання до інших термінів, якщо вони мають логічний зв’язок; г) указівки на відповідні терміни в інших мовах (переважно німецькій, іноді англійській, французькій); г) терміни-антоніми; д) іноді наведено терміни інших наук з тим самим 
Янчура Д. Словники ономастичних термінів у російському й українському мовознавстві: композиція, склад...

основним терміноелементом, що й той, який тлумачиться. У частині «Система отсылок», як засвідчує сама назва, обумовлено систему посилань, зокрема термінів-словосполучень (як правило, термін тлумачиться в словнику один раз; терміни-словосполучення з'являються в словнику стільки разів, скільки слів входить у це словосполучення: один раз із тлумаченням, інші з відсиланням, напр.: Поле ономастическое см. ономастическое, поле (кома означає, що основна стаття ономастический, а поле - підстаття); исконное имя см. собственное имя, исконное) (див. Подольская, 1978: 22). Частина «Терминоэлементы греческого и латинского языков», регулярно входящие в специальные термины ономастики, - це список грецьких і латинських префіксів, які, безумовно, спричиняються до надання термінам інтернаціонального характеру (див. Подольская, 1978: 23-24). Укладачка словника вже у вступі вказує на його недосконалість, уважаючи його неповним. Вона передбачливо наголошує, що деякі дефініції можуть бути неточні з огляду на неточність самих понять на той час. Однак цей словник цінний для російської і - ширше - слов'янської ономастичної термінології, хоча на сьогодні він і не надто актуальний, фіксує відносно небагато термінів.

Українська ономастика почала активно розвиватися лише в другій половині ХX століття. До розвитку термінологічної системи української мови спричинилася, зрозуміло, політична ситуація, порівн.: «Про вагу термінології в розвитку національної науки, культури й техніки може свідчити той факт, що після проголошення незалежності України в 1990 р. серед першочергових заходів, які довелося здійснювати молодій незалежній державі, було створення в 1992 р. Технічного комітету стандартизації науково-технічної термінології, і з цією ж метою в 2000 р. було створено Українське термінологічне товариство» (Бучко, \& Ткачова, 2012: 7).

В українському мовознавстві першою лексикографічною роботою, присвяченою українській ономастичній термінології, уважають опублікований Василем Німчуком 1966 року проєкт словника під назвою «Українська ономастична термінологія (Проект)». Мовознавці наголошують, що на сьогодні він став «абсолютно раритетним і практично недоступним для більшості молодих дослідників, які вивчають власні назви української мови, оскільки він був надрукований у малотиражному виданні Інституту мовознавства АН України 
ім. О. Потебні «Повідомлення української ономастичної комісії» ${ }^{1}$ (вип. перший накладом 300 примірників» (Бучко, \& Ткачова, 2012: 9).

Проєкт містить близько 100 українських ономастичних термінів, що співвідносяться зі згаданою вище загальнослов'янською ономастичною термінологією Яна Свободи (див. Svoboda, 1960). Пізніше з'явилися доповнення до цього списку. Зауважено, що не всі терміни, які знаходимо в цьому проєкті й доповненнях до нього, українські дослідники почали однаково активно використовувати, напр., не виявлено у вжитку термінів: алегрові форми імен - 'форми, що виникають унаслідок швидкого мовлення' (Ксана < Оксана), деглютинація (=декомпозиція), простеза (=аглютинація) та ін. (див. Бучко, \& Ткачова, 2012: 10). М. Торчинський пише, що «практично вся терміносистема науково достовірна», але «бажано було б звернути більше уваги на визначення джерела (мови) запозичення терміна та проілюструвати визначення прикладами» (Торчинський, 2008: 243). Значущість праці В. Німчука відзначає й Д. Бучко: «Без сумніву, опублікований В. Німчуком “Проект української ономастичної термінології і доповнення до нього” відіграли важливу роль у становленні української ономастичної термінології та розвитку української ономастики, одначе вони вже не можуть задовольнити сучасних потреб українських ономастів» (Бучко, \& Ткачова, 2012: 11).

Цінним для української ономастики, безумовно, $є$ одномовний галузевий тлумачний словник української ономастичної термінології, укладений Д. Бучком і Н. Ткачовою, який фіксує досягнення української ономастики, наявні на 2012 рік. Автори відзначають, що «пропонований (...) словник - це перше найповніше лексикографічне опрацювання української ономастичної термінології, використовуваної в українському мовознавстві» (Бучко, \& Ткачова, 2012: 23). Зрозуміло, що, «попри скромний тираж (всього 500 примірників), (словник) став настільною книгою і досвідчених ономастів, і ономастів-початківців» (Abuzarowa, 2016: 36). Він складається з таких частин: «Передмова» (с. 5-24), «Побудова словника» (с. 24-26), «Прийняті скорочення» (с. 27), «Використана література і джерела (с. 2830), «Словникові статті (с. 31-191), «Найважливіша ономастична

${ }^{1}$ Д. Бучко зауважує, що «на той час це був єдиний друкований орган з проблем ономастики в колишньому СРСР, тому сьогодні бібліотеки лише небагатьох вишів і тільки окремі бібліотеки найбільших міст України можуть похвалитися повним комплектом випусків (1-17) цього видання» (Бучко, \& Ткачова, 2012: 9). 
література. 3бірні та колективні праці» (с. 192-200), «Книги, статті та автореферати окремих авторів (список індивідуальних ономастичних досліджень за кілька останніх десятиліть, опублікованих в Україні, Білорусії, Росії, Польщі, Словаччині, Чехії, Болгарії)» (с. 200-232), «Ономастичні словники» (с. 233-237), «Періодичні видання (с. 238), «Бібліографія» (с. 238-239), «Найважливіші джерела для вивчення онімії України (рукописні й надруковані)» (с. 240-248), «Питальники» (с. 248), «Предметно-термінологічний покажчик» (с. 249-252), «Для нотаток» (с. 253). У цьому словнику в алфавітному порядку зафіксовано понад 2000 реєстрових слів з наголосами у формі називного відмінка однини (рідко множини). Автори намагаються показати взаємозалежність і взаємопідпорядкованість окремих термінів, зокрема родо-видові зв'язки між ними. «Коли між конкретними термінами існують родові та видові поняття, словникова стаття будується за гніздовим способом» (Бучко, \& Ткачова, 2012: 4). Автори прагнули «виробити спосіб тлумачення конкретних понять, а також знайти найбільш прийнятне лексикографічне трактування чинних взаємозв'язків між родово-видовими поняттями та їхніми назвами» (Бучко, \& Ткачова, 2012: 14). Тлумачення видових понять подано в одній статті з родовим поняттям (див. Бучко, \& Ткачова, 2012: 14). У передмові висвітлено значення термінології загалом, подано (а) визначення терміна, (б) історію виникнення української наукової термінології, зокрема й ономастичної, (в) перелік наявних українських словників ономастичної термінології, (г) чітко сформульовано конкретну мету - «тлумачення (...) термінів, а разом з тим і здійснення помірної їхньої систематизації та уніфікації» (Бучко, \& Ткачова, 2012:12). Автори переконливо аргументують важливість роботи Івана Ковалика для розвитку ономастичної термінології. Ідеться про принципи відбору й фіксації термінів, як-от: мінімалізація багатозначних термінів, актуальні значення, тобто такі, що витримали випробування часом. Окрім власне тлумачення ономастичної термінології, словник містить також список найважливішої, на думку авторів словника, і доступної ономастичної літератури (індивідуальні й колективні праці), список найдавніших і найповніших джерел для вивчення української антропонімії, ойконімії, гідронімії, а також список найвідоміших ономастичних словників та списки онімів (див. Бучко, \& Ткачова, 2012: 15). Серед джерел натрапляємо й на сучасну 
українську ономастичну літературу й довідники, що важливо, окрім термінології, запропонованої М. Торчинським, у монографії описано «Структуру оніміного простору», де йдеться про оригінальну авторську типологію онімів. Термінологія М. Торчинського, на думку авторів словника, надто деталізована й настільки індивідуальна, що не вписується в наявну сьогодні слов'янську систему ономастичних термінів (див. Бучко, \& Ткачова, 2012: 16). Можна тут знайти важливу інформацію про специфіку подання ономастичних термінів у сучасних термінологічних лінгвістичних словниках, інформацію про кількість слів у словнику (ïx 2000), висвітлено проблемні питання кваліфікації термінів, що стали неприйнятними, описано терміни, що мають однакове значення. Автори наголошують, що «питання впорядкування, систематизації, нормалізації та кодифікації системи української ономастичної термінології було й залишається однією з найважливіших проблем української ономастики» (Бучко, \& Ткачова, 2012: 23). Подібно до структури словника, укладеного Н. Подольською, усі реєстрові слова в лексикографічному виданні Д. Бучка й Н. Ткачової укладені за алфавітом й подані у формі називного відмінка однини (рідко множини). Якщо термін має форму словосполучення, то він з'являється в словнику стільки разів, скільки компонентів входить до його складу, однак дефініція такого терміна розкривається лише при домінувальному (стрижневому) його членові, а при інших складниках цього словосполучення подаються відсилання до основного слова (див. Бучко, \& Ткачова, 2012: 24). Словникова стаття починається із заголовного (реєстрового) слова. У круглих дужках після заголовного слова наведено варіанти основних термінів (застарілі, маловживані сьогодні назви), напр., ономастика (топономастика). У разі, коли маємо термін іншомовного походження, у дужках подається першоджерело запозичення цієї назви з указівкою (якщо в цьому є потреба) вихідної структури таких слів (див. Бучко, \& Ткачова, 2012: 24). Для полегшення читання і сприймання грецьких назв автори транслітерують їх латиницею, що важливо. Майже при кожному реєстровому слові для покращення можливостей орієнтування в іншомовних ономастичних текстах подано його відповідник англійською, німецькою, рідше французькою мовами (див. Бучко, \& Ткачова, 2012: 24). Коли ж конкретні терміни номінують родові й видові поняття, словникова стаття будується за гніздовим способом. Тлумачення більшості 
Янчура Д. Словники ономастичних термінів у російському й українському мовознавстві: композиція, склад...

термінів завершується ілюстративним матеріалом з української онімії (див. Бучко, \& Ткачова, 2012: 25).

Уважаємо за необхідне порівняти вказані два галузеві словники ономастичної термінології з огляду на їх обсяг і структуру. Словник Н. Подольської вважаємо застарілим, беручи до уваги рік видання й зроблене в ономастиці після виходу цього словника. Окрім цього, він містить відносно невелику кількість термінів - усього 700. Словник Д. Бучка і Н. Ткачової більш актуальний, оскільки новіший і більший за обсягом (2000 термінів), хоч, як видається, варто було б у ньому додати термінологічний покажчик і схеми, що продемонстрували $б$ наочно системність ономастичної термінології. Доречними й потрібними $є$ вказівки на варіативність та синонімію розглядуваних термінів.

Нагадаймо, що в контексті стандартизації ономастичної термінології не може бути єдиної універсальної понятійної системи доти, доки існують різні ономастичні школи (див. Janczura, 2018), що демонструють багатоликість сучасних лінгвістичних теорій і вивчають пропріальну лексику в різних мовних системах (див. Włoskowicz, 2018: 88). Важливо усвідомити факт співіснування в ономастичній теорії різних понятійних підсистем. Актуальним залишається й питання дефініювання ономастичних термінів. Ономастична термінологія “бореться" сьогодні насамперед $з$ проблемою синонімії, адже «для позначення одного й того ж денотата нерідко існує низка різних термінів» (Abuzarowa, 2016: 36). Прикладом може бути назва розділу ономастики, що вивчає оніми, які функціюють у літературно-художніх текстах. Напр., Донецька ономастична школа використовує терміни поетика оніма, поетонімологія (В. Калінкін), у працях представників Ужгородського ономастичного осередка функціює номінація літературно-художня ономастика (Л. Белей), засновник Одеської ономастичної школи Ю. Карпенко пропонує терміни літературна ономастика, ономастика художньої літератури (див. про це Janczura, 2018). Деякі науковці вказують на проблему псевдоомонімії. Зазначене ілюструє термін біблінім: одні мовознавці (О. Белей, Ю. Браїлко, О. Решетняк) використовують його в значенні 'назва біблійної постаті' (бібліонім як дериват від лексеми Біблія), інші (Д. Бучко, А. Загнітко, О. Карпенко) - як 'найменування будь-якого письмового твору - художнього, публіцистичного, релігійного, політичного, наукового тощо, порівн.: 
«автори, які використовують термін бібліонім на позначення назви біблійної постаті, виводять його від слова Біблія, а не безпосередньо від гр. biblion книга (хоча термін бібліонім і термін Біблія походять від одного й того ж грецького етимона biblion, в українській мові дериваційно вони не залежні між собою), тому й з'явилася псевдоомонімія» (Abuzarowa, 2016: 37).

Звернімо увагу й на необхідність розрізнення твірних основ в ономастичних термінах. Напр., для російського терміна антропонимический в українській ономастиці існує кілька термінів-паронімів, порівн.: антропонімний (від антропонім), антропонімійний (від антропонімія), антропонімічний (від антропоніміка), а також: антропонімна калька, антропонімійне явище, антропонімічна анкета (див. Казимирова, 2013). Те ж саме стосується російського терміна имя, що в українській мові має також три відповідники: назва (напр., имя собственное - власна назва), ім'я (напр., иноязычное имя - іншомовне ім'я), найменування (напр., имя рода - найменування для всієї родини) (див. Казимирова, 2013). Проблем, що торкаються перекладу ономастичних термінів, підбору аналогів, паралелей, зокрема й у проєкції на російську та українську ономастику, можна виокремити чимало. Описані приклади ілюструють деякі, що пов'язані з неточністю тлумачення ономастичної термінології, їі синонімією, омонімією, паронімією.

\section{Висновки}

Доходимо висновку, що термінологія української і російської ономастики потребує уніфікації, систематизації, уточнення з урахуванням досягнень слов'янської ономастики та національних традицій.

Словники ономастичної термінології і в українській, і в російській науці вимагають оновлення й доповнення. Однак українська ономастика, на відміну від російської, наприкінці XX - на початку XXI століття демонструє більш активний поступ, пропонуються нові підходи до укладання словників ономастичної термінології з більш послідовним урахування національної традиції та реалізації своєрідних авторських концепцій, підходів до окреслення базового списку термінів і їх інтерпретації в руслі загальнослов'янської традиції, що переконливо обгрунтовано авторами низки наукових студій. 
Янчура Д. Словники ономастичних термінів у російському й українському мовознавстві: композиція, склад...

Аналіз словників української і російської ономастичної термінології показує, що після виходу у світ словників, які аналізувалися, з'явилися нові ономастичні теорії в руслі поліфункційної прагматичної парадигми знань, які обслуговує низка нових термінів, що ще не стали об'єктом лексикографічної обробки. Крім того, спостерігаємо розходження в розумінні одних і тих самих термінів, формується не лише термінологічна полісемія, але й омонімія, зокрема й міжмовна, простежуємо наявність різних термінологічних варіантів, по-різному репрезентовано системні зв'язки. Українська й російська ономастична наука реалізує відмінний шлях розвитку, що засвідчує менше фактів збігу, тому й слід глибше усвідомити та описати міжмовні термінологічні паралелі.

3 огляду на те, що порівняльних досліджень у галузі ономастики з'являється все більше, а наукові міжнародні контакти вдосконалюються й активізуються, убачаємо потребу укладання не лише одномовних, але й двомовних та багатомовних словників термінів ономастики. Початком цієї роботи може стати українсько-російський і російсько-український словник ономастичної термінології, оскільки це важливо для зіставних досліджень. У добу глобалізації доцільно було 6 створити електронне видання одномовного та багатомовного словника ономастичних термінів на зразок системи $\mathrm{ICOS}^{2}$, де зафіксовані найважливіші ономастичні терміни англійською, німецькою і французькою мовами, що, безумовно, спричинилося 6 до популяризації наукових досліджень у міжнародному просторі.

\section{ЛІТЕРАТУРА}

1. Ахманова, О. С. (1966). Словарь тингвистических терминов. Москва: Сов. энцикл. 2. Белецкий, А. А. (1972). Лексикология и теория языкознания: Ономастика. Киев: Изд-во Киев. ун-та. 3. Бучко, Д., \& Ткачова, Н. (2012). Словник української ономастичної термінологіi. Харків: Ранок-НТ. 4. Загнітко, А. (2013). Словник сучасної тінгвістики: поняття і терміни. Донецьк: ДонНУ. 5. Казимирова, І. А. Ономастична термінологія української мови в аспекті проблеми гармонізації. Мова і культура, 16, 186-193. 6. Ковалик, I. I. До упорядкування системи українських ономастичних термінів. Повідомлення української ономастичної комісії, 14, 20-27. 7. Космеда, Т. (2019). Термінологічна наукова школа професора Ірини Миколаївни Кочан (присвячується 70-літтю вченої). В У вимірах слова (с. 7-21). Львів; Дрогобич: Посвіт. 8. Німчук, В. В. Українська ономастична термінологія (Проект). Повідомлення української ономастичної комісії, 1, 24-43. 9. Подольская, Н. В. (1978). Словарь русской ономастической

\footnotetext{
${ }^{2}$ Див. The International Council of Onomastic Sciences. Узято з https://icosweb.net.
} 
терминологии. Москва: Наука. 10. Суперанская, А. В. (2009). Ономастика начала XXI века. Москва: Ин-т языкознания РАН. 11. Супрун, В. І. Размышления над ономастической терминологией. Вестн. Волгогр. гос. ун-та, 8 (62), 133-138. 12. Торчинський, М. М. Словник української ономастичної термінології (засади, структура, коментарі). Украӥнське мовознавство, 38, 243-247. 13. Abuzarowa, М. Явище синонімії в українській ономастичній термінологіï. Zeszyty Cyrylo-Metodiańskie, 5, 35-44. 14. Janczura, D. Ономастичні школи в Україні. Studia Ukrainica Posnaniensia, 6, 4552. 15. Svoboda, J. K slovanské onomastické terminologii. Zpravodaj Místopisné komise ČSAV, 1, 273-284. 16. Włoskowicz, W. O pojęciach, systemach pojęciowych i terminologii onomastycznej. Onomastica, 62, 73-98.

\section{REFERENCES}

1. Axmanova, O. S. (1966). Slovar' lingvisticheskix terminov [Dictionary of linguistic terms]. Moskva: Sov. e'ncikl. [in Russian]. 2. Beleckij, A. A. (1972). Leksikologiya $i$ teoriya yazykoznaniya: Onomastika. [Lexicology and the theory of linguistics: Onomastics] Kiev: Izd-vo Kiev. un-ta [in Russian] 3. Buchko, D., \& Tkachova, N. (2012). Slovnyk ukrainskoi onomastychnoi terminolohii [Dictionary of Ukrainian onomastics terminology]. Kharkiv: Ranok-NT [in Ukrainian]. 4. Zahnitko, A. (2013). Slovnyk suchasnoi linhvistyky: poniattia i terminy [Dictionary of modern linguistic: concepts and terms] Donetsk: DonNU [in Ukrainian]. 5. Kazymyrova, I. A. Onomastychna terminolohiia ukrainskoi movy v aspekti problemy harmonizatsii [Ukrainian onomastic terminology with the framework of the issue of harmonisation]. Mova i kultura - Language and culture, 16, 186-193 [in Ukrainian]. 6. Kovalyk, I. I. Do uporiadkuvannia systemy ukrainskykh onomastychnykh terminiv [On the standardisation of Ukrainian onomastic terms]. Povidomlennia ukrainskoi onomastychnoi komisii - The statement of the Ukrainian onomastic committee, 14, 20-27 [in Ukrainian]. 7. Kosmeda, T. (2019). Terminolohichna naukova shkola profesora Iryny Mykolaivny Kochan (prysviachuietsia 70-littiu vchenoi) [Terminological research school of Professor Iryna Kochan (on the occasion of the scholar's $70^{\text {th }}$ birthday)]. In $U$ vymirakh slova - In the universe of words (pp. 7-21). Lviv; Drohobych: Posvit [in Ukrainian]. 8. Nimchuk, V. V. Ukrainska onomastychna terminolohiia (Proekt) [Ukrainian onomastics terminology (Project)]. Povidomlennia ukrainskoi onomastychnoi komisii - The statement of the Ukrainian onomastic committee, 1, 24-43 [in Ukrainian]. 9. Podol'skaya, N. V. (1978). Slovar' russkoj onomasticheskoj terminologii [Dictionary of Russian onomastics terminology]. Moskva: Nauka [in Russian]. 10. Superanskaya, A. V. (2009). Onomastika nachala XXI veka [Onomastics of the beginning of the XXI century]. Moskva: In-t yazykoznaniya RAN [in Russian]. 11. Suprun, V. I. Razmyshleniya nad onomasticheskoj terminologiej [Some thoughts on onomastic terminology]. Vestn. Volgogr. gos. un-ta - The herald of Volgograd State University, 8 (62), 133-138 [in Russian]. 12. Torchynskyi, M. M. Slovnyk ukrainskoi onomastychnoi terminolohii (zasady, struktura, komentari) [Dictionary of Ukrainian onomastics terminology (principles, structure, comments]. Ukrainske movoznavsvto Ukrainian linguistics, 38, 243-247 [in Ukrainian]. 13. Abuzarowa, M. Yavyshche synonimii $\mathrm{v}$ ukrainskii onomastychnii terminolohii [The phenomenon of synonymy in Ukrainian onomastic terminology]. Zeszyty Cyrylo-Metodiańskie - Cyril and Methodius' notebooks, 5, 35-44 [in Ukrainian]. 14. Janczura, D. Onomastychni shkoly v Ukraini [Onomastics schools in Ukraine]. Studia Ukrainica Posnaniensia, 6, 45-52 [in Ukrainian]. 15. Svoboda, J. 
K slovanské onomastické terminologii [On the Slavic onomastic terminology]. Zpravodaj Místopisné komise ČSAV, 1, 273-284. 16. Włoskowicz, W. O pojęciach, systemach pojęciowych i terminologii onomastycznej [On concepts, conceptual systems and terminology of onomatics]. Onomastica, 62, 73-98.

Янчура Домініка - магістр, аспірант кафедри україністики Інституту російської й української філології, Університет імені Адама Міцкевича; ал. Неподлеглості, 4, м. Познань, Польща, 61-874.

Tel.: +48 731911709

E-mail: dominikajanczura@interia.eu

https://orcid.org/oooo-0001-5634-7044

Yanchura Dominika - Master Student, Postgraduate Student at the Departament of Ukrainian Studies, Institute of Russian and Ukrainian Philology, Adam Mitskevych University; 4 Niepodległości Al., Poznań, 61-874, Poland.

Надійшла до редакції 28 січня 2021 року

\section{CITATION}

ДСТУ 8302:2015: Янчура Д. Словники ономастичних термінів у російському й українському мовознавстві: композиція, склад, способи інтерпретації та проблема дефініювання. Лінгвістичні дослідження: зб. наук. пр. Харк. нац. пед. ун-ту імені Г. С. Сковороди. Харків, 2021. Вип. 54. Ч. I. С. 243-257. DOI: https://doi.org/10.34142/ 23127546.2021.54.1.21

APA: Янчура, Д. (2021). Словники ономастичних термінів у російському й українському мовознавстві: композиція, склад, способи інтерпретації та проблема дефініювання. Лінгвістичні дослідження, 54 (I), 243-257. DOI: https://doi.org/10.34142/ 23127546.2021.54.1.21 